\title{
Correction to: Technological Transformation: \\ A New Role For Human, Machines And Management
}

Hanno Schaumburg, Vadim Korablev, and Laszlo Ungvari

\section{Correction to:}

H. Schaumburg et al. (Eds.): Technological Transformation:

A New Role For Human, Machines And Management, LNNS 157, https://doi.org/10.1007/978-3-030-64430-7

In the original version of the book, the following correction has been incorporated: The name of the editor has been amended. The book has been updated with the change. 